Case Report

\title{
Integration of Renewable Energy Resources to Utility Distribution Network: A Case Study of Hussaini Adamu Federal Polytechnic Kazaure Jigawa State Nigeria
}

\author{
John Ohabuiro, Abba Mohammed, Danladi Agadi Tonga \\ Department of Electrical and Electronic Engineering, Hussaini Adamu Federal Polytechnic, Kazaure, Nigeria \\ Email address: \\ nkeonyejohn@gmail.com (J. Ohabuiro)
}

\section{To cite this article:}

John Ohabuiro, Abba Mohammed, Danladi Agadi Tonga. Integration of Renewable Energy Resources to Utility Distribution Network: A Case Study of Hussaini Adamu Federal Polytechnic Kazaure Jigawa State Nigeria. American Journal of Modern Energy.

Vol. 7, No. 3, 2021, pp. 27-35. doi: 10.11648/j.ajme.20210703.11

Received: December 28, 2020; Accepted: January 12, 2021; Published: June 25, 2021

\begin{abstract}
Nigeria is a country in West African region of the world blessed with enormous potential of renewable energy resources such as wind, hydro, solar, animal waste and municipal waste. Despite the availability of these energy resources in large quantity, the country is still ranked among the countries in the world with very poor access to electricity. This paper tends to suggest an approach towards solving the problem of irregular supply of electricity in Hussaini Federal Polytechnic located in Jigawa, a state in northwestern part of Nigeria. This approach involves sectionalizing the polytechnic into two sections and integrating photovoltaic energy system to an already existing utility distribution network in each of the sections. These interconnected energy sources are to be used in charging the storage systems located within each of the sections. Electricity will be supplied to the load in a particular section from the storage system located within the section, through existing distribution network in the polytechnic. The sizing of the storage system, the inverter, the charge controller and the photovoltaic array were done by normal renewable energy system calculation. From the results obtained, each of the sections will require a set of $250 \mathrm{~kW}$ $480 \mathrm{~V}$ hybrid inverter, twenty thousand pieces of $250 \mathrm{~W} / 24 \mathrm{~V}$ photovoltaic panels and $2,798.5 \mathrm{kWh}$ battery capacity.
\end{abstract}

Keywords: Integration, Photovoltaic System, Distribution Network, Sizing

\section{Introduction}

Electricity plays an important role in industrializing a country. It can as well cause an increase in the number of people migrating from rural dwellings to urban areas. These two important roles can greatly help a country grow economically and consequently, reduce the number of people living in poverty [1]. Worldwide, there was a tremendous increase in electricity generation and consumption in 2017 alone compared to previous years. This is attributed to an increase in population growth and rapid industrialization caused by increased economic activities [2]. In 2017, most of the growth experienced in electricity generation in the world happened in Asia with China accounting for about $50 \%$ of it. There was noticeable increase in other Asian countries like Japan and India. Out of the $818 \mathrm{TW}$ of electricity generated in Africa in 2017, Nigeria accounted for $3.4 \%$ of it [3].
Most of these electricity generations come from non-renewable sources like fossil fuel. Electricity generation from these sources has become of great concern in the world due to its associated problems such as; rise in the cost of gas, great rate of fossil fuel depletion and green house emission. There is also a great concern regarding increased demand for electricity. These concerns have led to intense research on renewable energy sources [4-6]. Generation of electricity from renewable sources has increased in recent years. It contributed about $50 \%$ of the growth experienced in world electricity generation in 2017. There is also rapid growth of renewable power generation as it increased by $17 \%$ in 2017 as so many countries now generate bulk electricity from renewable sources. Denmark generates $68 \%$ of its total power from renewable energy sources. The share of power generated from renewable sources in UK, Italy, Germany and Spain are 28\%,23\%,30\%, 25\% respectively [7]. Electricity generation from renewable energy sources in Africa is still very 
low despite its high renewable energy potential. Large percentage of the energy generated from renewable sources in Africa is from hydroelectric sources. [8]

\section{World Electricity generation 2017}

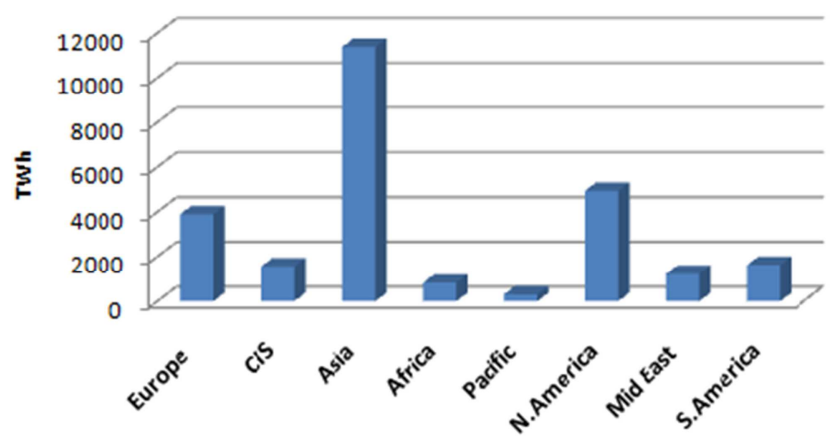

Figure 1. World Electricity production 2017. [3]

The level of underdevelopment in most third world countries is not unconnected with inadequate supply of electricity in these countries. According to a report by The International Centre for Energy, Environment and Development (ICEED), about $40 \%$ of the people living in Nigeria are connected to the grid and the supply from the grid is so unreliable. [9]. This accounts for why poverty rate is still high in Nigeria. [10] The situation in Nigerian schools is not different as about $65 \%$ of schools in Nigeria lack access to electricity. [11]. Without proper Electrification of schools, teaching and learning will become too tedious. Access to electricity in schools will ensure that classes are properly illuminated. It will also facilitate use of information and communication equipment in teaching and learning thereby leading to enhanced performance of the students. [12]. Educating the populace properly is another vital approach towards improving the economy of a country and consequently improving their standard of living. [13]
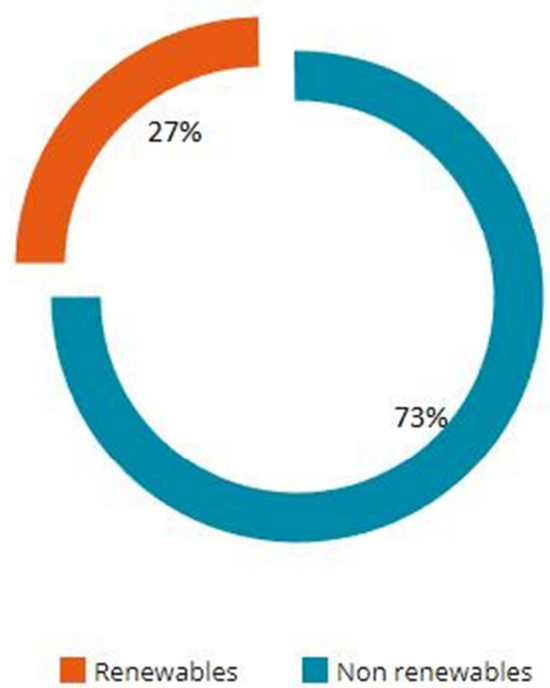

Figure 2. Percentage of world electricity production from renewable and non-renewable sources in 2017. [3]
This work suggests a reliable approach towards solving the energy problem in Hussaini Adamu Federal Polytechnic Kazaure by sizing and integrating a hybrid renewable energy system comprising of photovoltaic energy system and storage energy system to a utility distribution network that supplies electricity to the polytechnic. The objectives are

1. To estimate the energy demand based on academic activities in the polytechnic

2. Appropriate sizing of the storage system, and photovoltaic system based on the estimated energy demand, solar irradiation and temperature in Kazaure

3. To suggest an operational strategy for effective management of the system.

\section{Existing Condition}

Nigeria is a federal republic in West Africa comprising 36 states and the Federal Capital Territory, with a population of 186 million. [14] The first time electricity was produced in Nigeria was in 1898 when 2 sets of $30 \mathrm{kw}$ generating plants were installed in Lagos mainly for street lighting in Marina Lagos between $6 \mathrm{pm}$ to $11 \mathrm{pm}[15,16]$. There were attempts at coordinating the activities of the sector. The legislative council in 1950 established a central body known as the Electricity Corporation of Nigeria (ECN) to handle electricity supply and development. There was also the establishment of Native Authorities and the Nigerian Electricity Supply Company (NESCO), which had license to produce electricity in some locations in Nigeria. In 1972, these two bodies were later merged into a new body known as National Electric Power Authority (NEPA) to coordinate electricity production in Nigeria and at same time ensure that the human, financial and other resources available in the electricity supply sector were effectively utilized. [17]

The growth in population over the years did not correspond to growth in the electricity production. Prior to 1999 , there was no substantial investment in the power sector. New plants were not built and the existing ones were not properly maintained which drastically reduced the power generation to about $1750 \mathrm{~mW}$ from the installed capacity of about $5600 \mathrm{~mW}$. [18] Presently, the installed generation capacity is about $12,500 \mathrm{~mW}$ out of which $85 \%$ comes from natural gas. The transmission capacity is about $4500 \mathrm{~mW}$ and only about $25 \%$ of the installed capacity reaches the consumers. [19]

This is quite low in a country where many citizens do not still have access to electricity. This low power generation coupled with other factors contributes to the reason the managers of the energy sector in Nigeria indulge in load sharing which makes it possible for the cities connected to the grid to get electricity for at least few hours within a day. Kazaure is a local government area in Jigawa state located in North West Nigeria. The unpredictable nature of supply from the utility affects the educational institutions located in the town of which Hussaini Adamu Federal Polytechnic Kazaure is among. The polytechnic was established in December 1991 as Jigawa State Polytechnic for providing technical and practical training to satisfy the manpower requirements for the industrial and economic 
development of Nigeria. At inception, it had only four colleges located at different cities in the state while the central administration office was located in Kazaure. In 1998, the polytechnic was renamed Hussaini Adamu polytechnic to honor former emir of Kazaure and was later made a federal polytechnic in 2007. The polytechnic is presently running seventeen national diploma courses and five higher national diploma courses [20,21]. The power demand of the polytechnic is about $1622.1 \mathrm{~kW}$ [22]. The energy to satisfy this load basically come from the utility and some diesel generators installed at different locations in the school environment. Most of the generators are already in deplorable state and the supply from utility to the school is highly unpredictable and unreliable just as it is the case all over Nigeria. This work will focus on meeting the energy demand of the main campus, which has a total connected load of about $398 \mathrm{~kW}$.

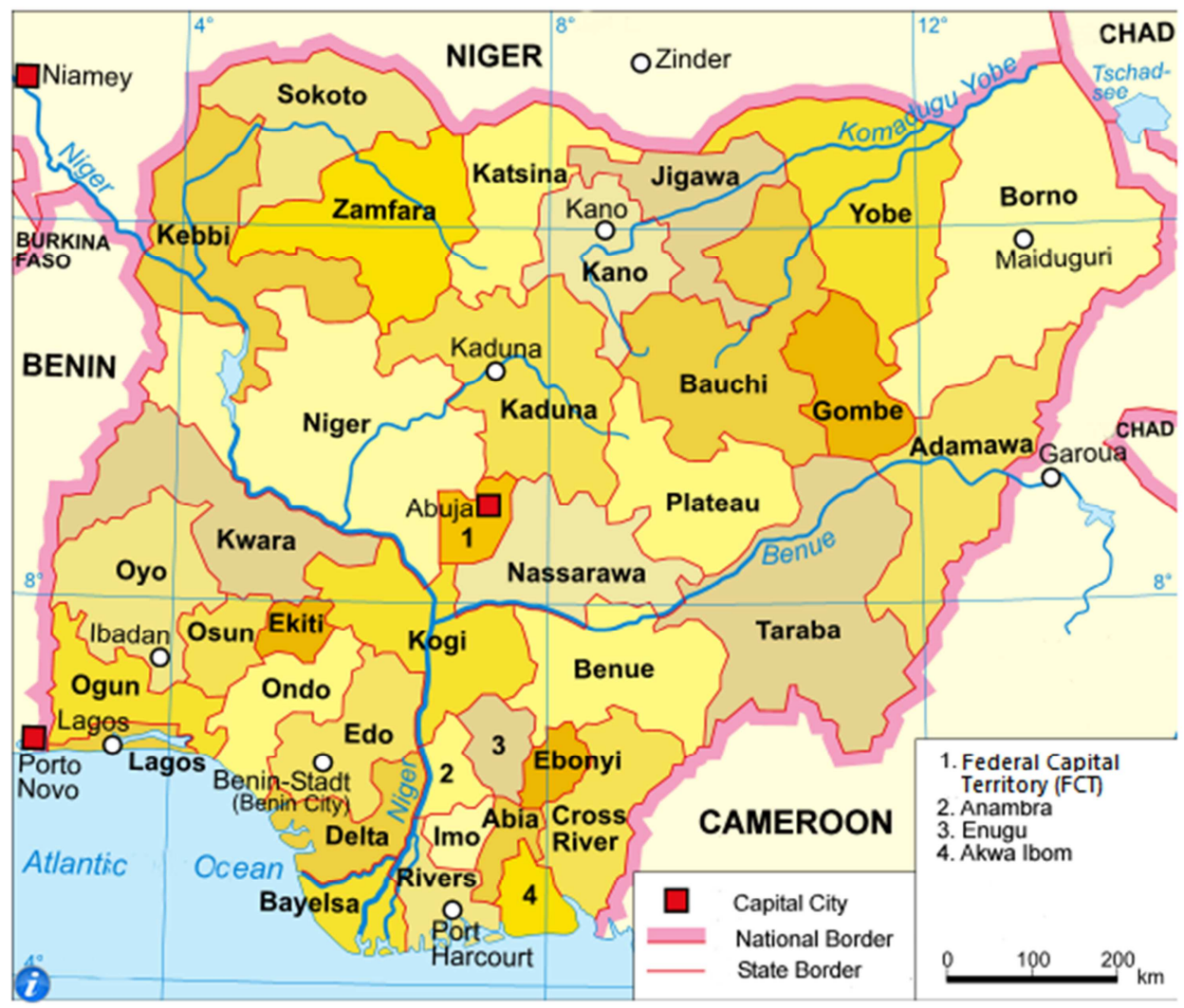

Figure 3. Map of Nigeria (source en.wikipedia.org).

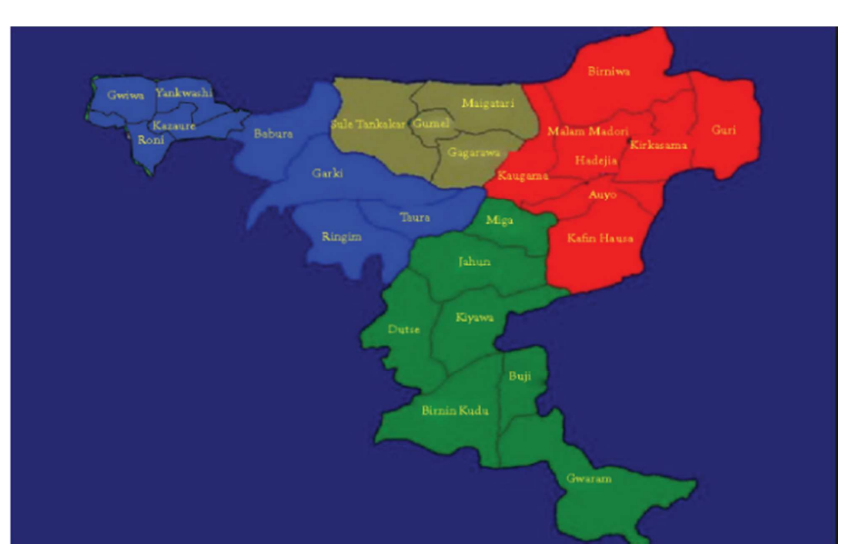

Figure 4. Map of Jigawa state showing Kazaure (source coastguard.gov.IK).

\subsection{Renewable Energy Potential in Nigeria}

The quantity of solar energy that radiates from the sun is large enough to satisfy the energy demand of the world. Viewing from the earth between latitudes $15^{\circ} \mathrm{N}$ and $35^{\circ} \mathrm{N}$, it was observed that the sun is positioned in the region with the most solar energy and these regions are located in Western United State, Africa, India and the Middle East. [23] Nigeria falls within these rejoins and thus, has huge potential for solar energy resources. On average, the daily solar irradiation in Nigeria ranges between $3.5 \mathrm{kWh} / \mathrm{M}^{2} /$ day in the southern part and $7 \mathrm{kWh} / \mathrm{M}^{2} /$ day in the northern part, with an average daily sunlight hours of about 6hour per day. If the solar energy resource in Nigeria is well harnessed, the country has the capacity to generate about $1850 \times 103 \mathrm{gWh}$ of electricity from solar energy in one year. [24]. There is also abundant wind energy in Nigeria although the wind speed varies from city to city. In the southern part, the wind speed ranges from $5.04-$ $10.8 \mathrm{Km} / \mathrm{h}$ whereas in the far northern part of Nigeria, it ranges from $14.4-18.432 \mathrm{Km} / \mathrm{h}$. it has been established that in Sokoto, the exploitable wind energy reserve at 10 meter height could get to $97 \mathrm{mWh} /$ year while it could get to $51 \mathrm{mWh} /$ year Jos. [25] Other renewable energy resources available in Nigeria include: Biomass, hydro and geothermal. [26, 27]

In Kazaure, average monthly daily solar irradiation ranges between $5.1 \mathrm{Kwh} / \mathrm{M}^{2} /$ day and $6.7 \mathrm{Kwh} / \mathrm{M}^{2} /$ whereas the average monthly daily wind speed ranges from $5.04-$ $10.8 \mathrm{Km} / \mathrm{h}$. the minimum temperature is 20.9 while maximum 
temperature is 31.7 .

figure 7 shows average monthly temperature in Kazaure.

Figure 6 shows the average monthly solar radiation whereas

Table 1. Potential of renewable energy in Nigeria. [27]

\begin{tabular}{|c|c|c|c|}
\hline Resource Type & Reserves (Natural Units) & Production Level (natural units) & Utilization (natural units) \\
\hline Hydropower, large scale & $11,250 \mathrm{~mW}$ & 1,938 MW (167.4 million mWh/day) & 167.4 Million $\mathrm{mWh} /$ day \\
\hline Hydropower, small scale & $3,500 \mathrm{~mW}$ & $30 \mathrm{MW}$ ( 2.6 million mWh/day) & 2.6 million $\mathrm{mWh} /$ day \\
\hline Solar Radiation & $\begin{array}{l}3.5-7.0 \mathrm{kWh} / \mathrm{m}^{2} / \text { day }(485.1 \text { million } \\
\mathrm{mWh} / \text { day using } 0.1 \% \text { Nigeria land area) }\end{array}$ & $\begin{array}{l}\text { Excess of } 240 \mathrm{kWp} \text { of solar PV or } 0.01 \\
\text { million } \mathrm{mWh} / \text { day }\end{array}$ & $\begin{array}{l}\text { Excess of } 0.01 \text { million } \mathrm{mWph} / \text { day } \\
\text { of solar PV }\end{array}$ \\
\hline Wind & $(2-4) \mathrm{m} / \mathrm{s}$ at $10 \mathrm{~m}$ height & & \\
\hline $\begin{array}{l}\text { Biomass: } \\
\text { Fuel wood Animal waste } \\
\text { Energy Drops and Agric } \\
\text { Residue Municipal waste }\end{array}$ & $\begin{array}{l}11 \text { million hectares of forest and Wood and } \\
245 \text { million assorted animals in } 2001 \\
72 \text { million hectares of Agric Land and all } \\
\text { waste lands - } 18.3 \text { million tonnes in } 2005 \text { \& } \\
\text { about } 30 \text { million tonnes/yr now }\end{array}$ & $\begin{array}{l}0.110 \text { million tonnes/day } 0.781 \text { million } \\
\text { tonnes of waste/day in } 2001 \text { Excess of } \\
0.256 \text { million tonnes of assorted crops } \\
\text { residues/day in } 1996\end{array}$ & \\
\hline Geothermal & 6 sites & & \\
\hline Wave and Tidal Energy & $150,000 \mathrm{TJ} /(16.6 \times 106$ toe/year & & \\
\hline
\end{tabular}

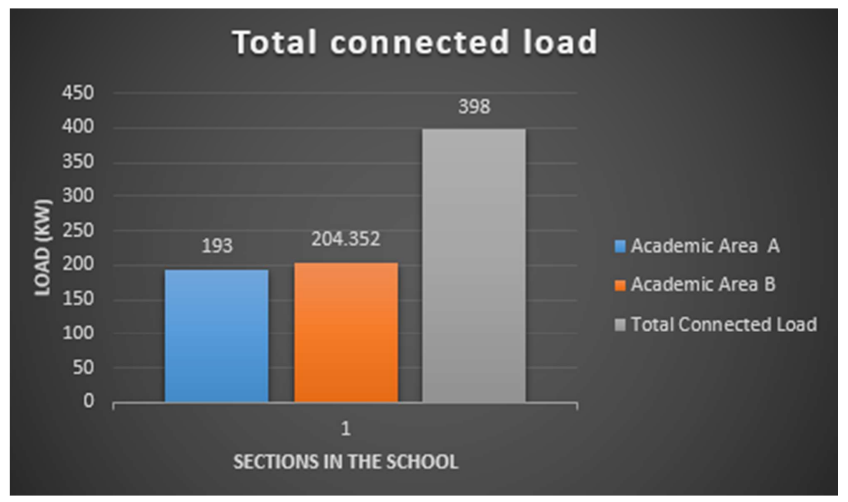

Figure 5. Total Connected Load.

\subsection{Nigeria Policy on Renewable Energy}

Nigeria has over the years came up with different policies on the development of the renewable energy resources that are abundantly available in the country. One of such policies is the national renewable energy and energy efficiency policy (NREEEP) approved by Nigerian federal executive council in 2015 for the electricity sector. The policy focuses on encouraging the development of Hydropower, Biomass, Solar, Wind, Geothermal, Wave and Tidal Energy for electricity generation in Nigeria in order to minimize the effects of fossil fuel on the climate and at same boost electricity production in Nigeria. This paper focuses on the key policy regarding solar and wind [29].

On solar, the key policies are as highlighted below

i. The nation shall effectively harness solar energy resources and integrate them with other energy resources.

ii. The nation shall promote the use of efficient solar energy conversion technologies, such as use of photovoltaic, solar-thermal and concentrated solar panels for power generation.

iii. The nation shall promote solar energy generation for productive use.

iv. The nation shall intensify efforts to increase the percentage of solar energy in the present energy mix.

$\mathrm{v}$. The nation shall promote the development of energy storage technologies. vi. The nation shall compliment solar power development with energy efficiency programs.

On wind;

1) The nation shall commercially develop its wind energy resource and integrate this with other energy resources into a balanced energy and electricity mix.

2) The nation shall take necessary measures to ensure that this form of energy is harnessed at sustainable costs to both suppliers and consumers in the rural areas.

3) The nation shall ensure the development of indigenous small-scale wind generating devices and energy storage devices.

A. Hybrid Renewable Energy System

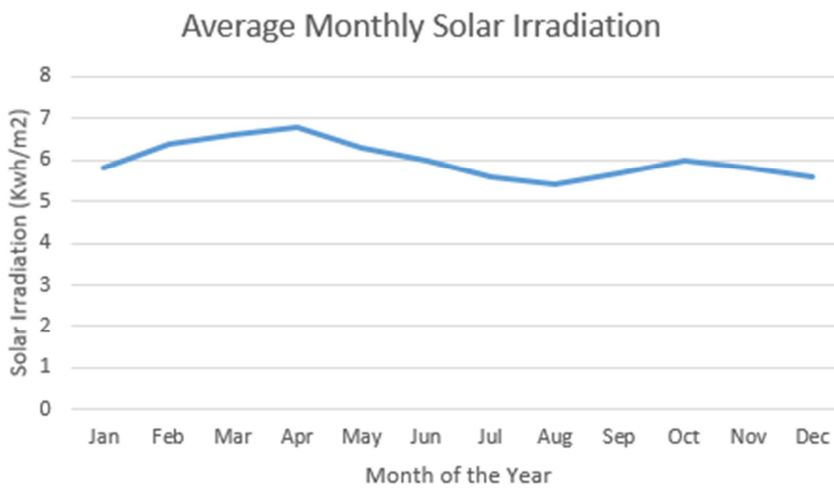

Figure 6. Average Monthly Solar Radiation in Kazaure. [28] Average Monthly Temperature

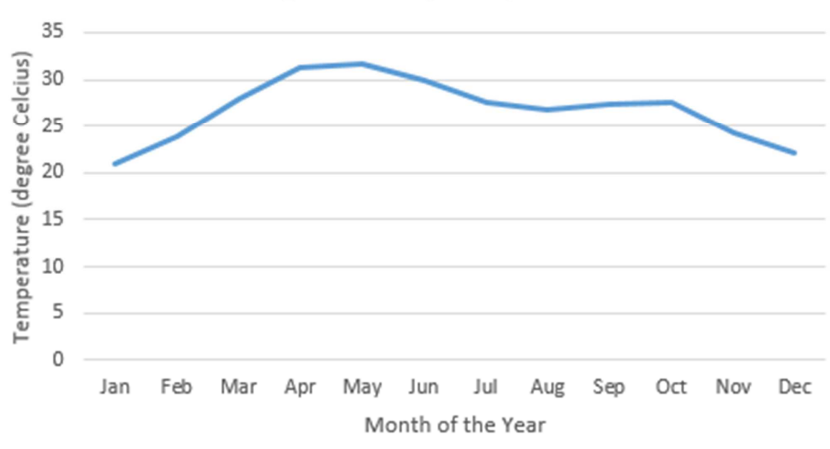

Figure 7. Average Monthly Temperature in Kazaure. [28] 


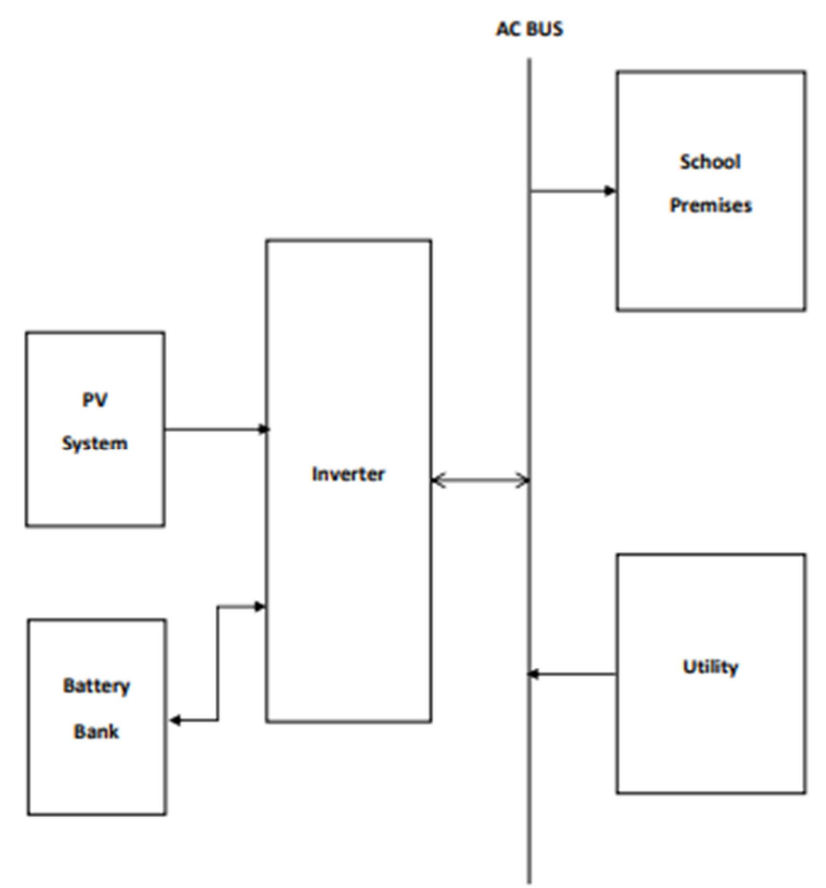

Figure 8. Block Diagram of the Proposed Hybrid System.

Hybrid Renewable Energy Systems (HRES) is obtained by combining non- renewable energy source with a renewable energy source or combining two or more renewable energy sources [30]. The introduction of HRES becomes necessary due to the intermittent nature of renewable energy sources such as wind and solar. It helps in improving the system reliability and its operational efficiency [31]. Some of the important components of the system are the power electronics and storage systems. Converters play important roles in a hybrid energy system. They can convert AC voltage to DC or convert DC voltage to AC voltage and can as well step up or step down AC voltage and DC voltage. Step up converters are called boost converters whereas the step down converters are called buck converter. In a hybrid renewable energy system the output of the solar system and that of the wind energy system are connected to boost converter in order to match the dc-bus voltage. A boost converter could have an inbuilt controller that helps it track the maximum power points of the wind or the solar. This is to prevent power loss and ensure that the output voltage of the converter boosts up to the desired value [31]. Another very important component is the energy storage system. They can be defined as the storage of energy in mechanical, chemical or electrical form. Storage systems are used to stabilize the system voltage and to store energy for future use. They generally help in improving the overall efficiency and reliability of entire hybrid system. There are different types of energy storage systems in use today such as Batteries energy storage system, Hydrogen energy storage system, Flywheel energy storage system, Pumped Hydro energy storage system, Compressed Air energy storage system, Super capacitor energy storage system, Superconducting Magnetic energy storage system and Thermal energy storage system [32-34].

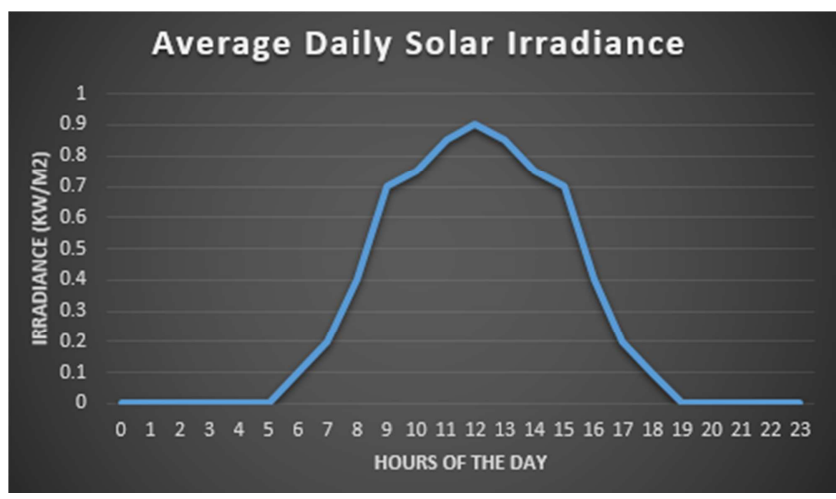

Figure 9. Average Daily Solar Irradiance in Kazaure.

\section{Methods}

\section{A. Energy Demand in the polytechnic}

The energy demand estimated based on the activities in the Polytechnic shows that the daily energy demand in section A is $1294 \mathrm{kWhwhereas}$ that of section B $1306 \mathrm{kWh}$.

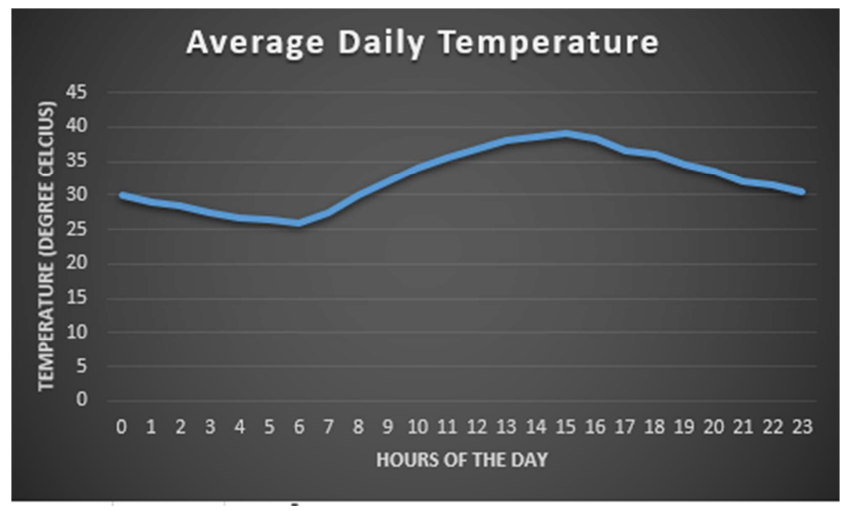

Figure 10. Average Daily Temperature in Kazaure.

\section{B. Inverter sizing}

Inverters rating are mostly in watt, kilowatt, or megawatt. In sizing an inverter for a particular system, the power rating of the energy source and that of the connected load are considered. In this work, the size of the inverter depends on the power rating of the connected load and possible power surge. Power surge relates to the extra power that an inverter can support outside the inverter's power rating. It is always proper to consider a safety factor of 1.25.

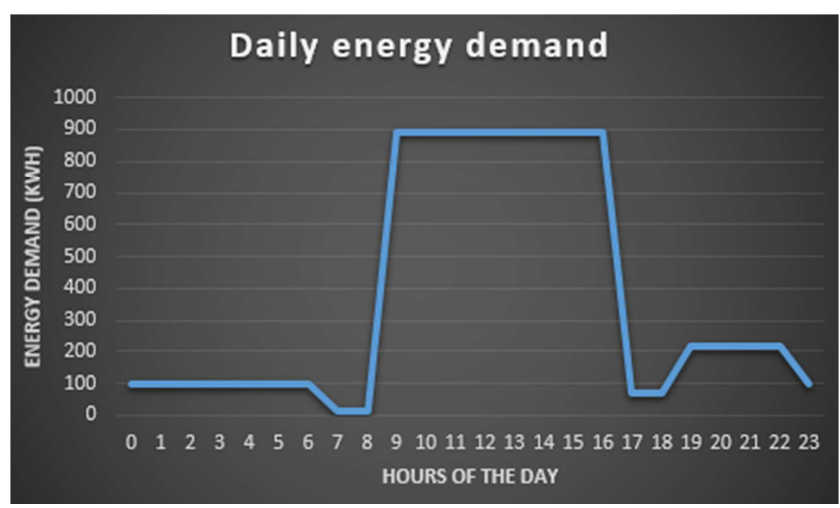

Figure 11. Daily Energy Demand in Section A. 


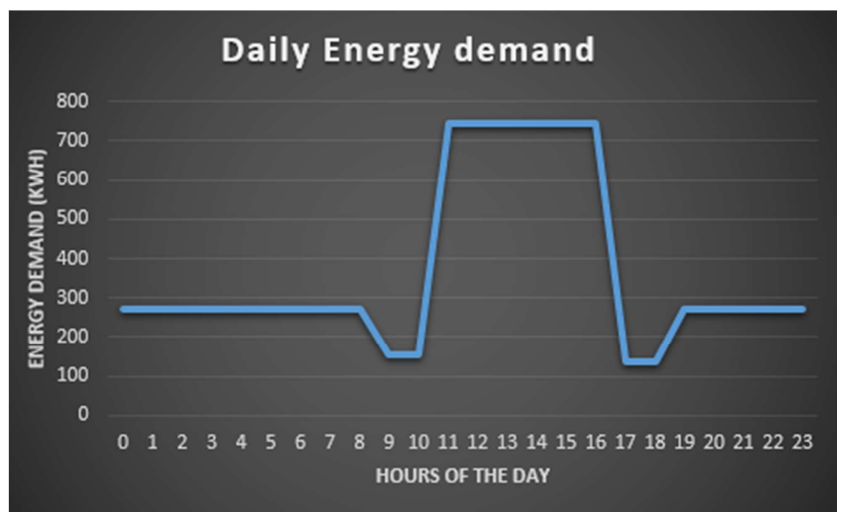

Figure 12. Daily Energy Demand at Section B.

\section{Battery capacity sizing}

Photovoltaic and wind energy systems are both intermittent sources of energy. This makes it necessary for incorporation of storage systems to a hybrid energy system. The storage system for this work is the battery storage systems and the type of battery is the lead acid battery that is popularly used for grid connected hybrid systems. Batteries smooth out the fluctuation of wind and solar power and also improve the load availability [35]. The battery capacity needed for a given energy demand depends on the charge required from the battery and the depth of discharge of the battery. The battery can be calculated as follows;

$$
B_{\text {cap }}=\frac{C_{r}}{B_{D O D}}
$$

Where

$B_{c a p}:$ Required Battery capacity (kAh)

$C_{r}:$ Required charge (kAh)

$B_{D O D}$ : Battery depth of discharge

The equation below calculates the required charge.

$$
C_{r q}=\frac{E_{r q}}{V_{h s}}
$$

Where

$E_{r q}:$ Required energy

$V_{h s}$ : Hybrid system voltage

The number of series and parallel-connected batteries is calculated as shown below;

$$
\begin{gathered}
B_{s}=\frac{V_{h s}}{V_{b a t}} \\
B_{p}=\frac{B_{c a p}}{B_{s e l}}
\end{gathered}
$$

Where

$B_{n s}:$ Number of series connected batteries

$B_{n p}$ : Number of parallel-connected batteries

$V_{\text {bat }}$ : battery nominal voltage

$B_{\text {rat }}$ : selected battery rating (Ah)

D. $P$ V array sizing

Photovoltaic systems depend on the availability of solar energy and therefore, are sized in such a way that they can provide the electrical energy required from them during the daytime when there is still availability of sunlight.

The equation below determines the size of PV array needed to satisfy any given energy demand.

$$
\begin{gathered}
P V_{a r}=\frac{B_{c a p}}{P V_{\text {dopt }}} \\
P V_{\text {dopt }}=P V_{\text {arc }} \times \text { eff } x P S H
\end{gathered}
$$

Where

$P V_{\text {dopt }}$ : dialy PV array output (kWh)

$P V_{\text {ar }}$ : Required PV array

$P V_{\text {arc }}: P V$ aray capacity $(k W)$

eff: efficiency

$P S H$ : peak sun hours $(h)$

\section{E. Charge Controller Sizing}

When charging the batteries from renewable energy sources, it is necessary to regulate the charging in order to prevent the batteries from overcharging and to ensure that energy from the batteries is not sent back to the charging source [37]. Charge controllers are incorporated in the system to make that happen. In sizing the controller for photovoltaic system, the system voltage and the output current from the PV array must be considered. It is also important to consider that the PV array sometimes produces more than their rated current. This must also be considered in sizing charge controllers by sizing it with a safety factor of 1.25 of the expected current output from the array.

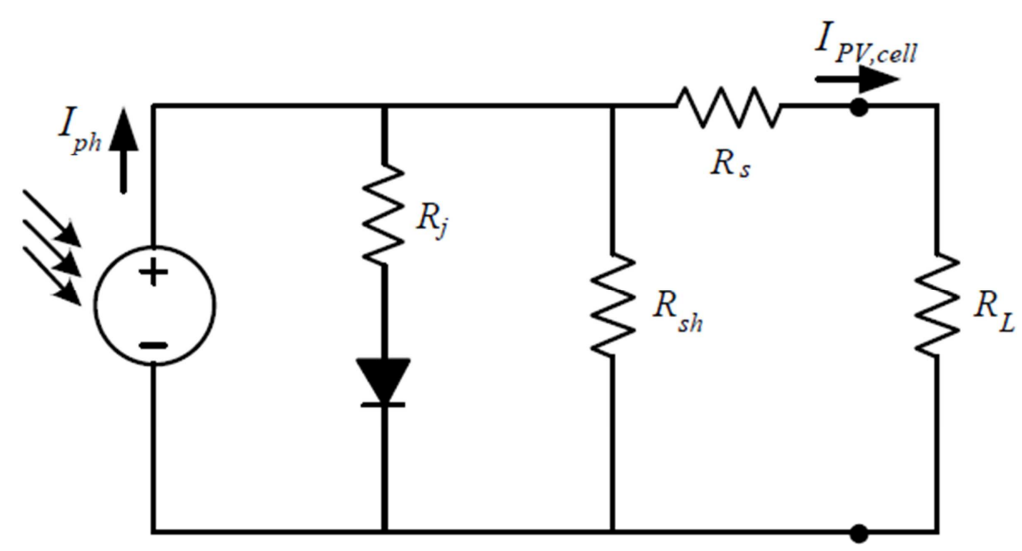

Figure 13. Circuit Diagram of a Photovoltaic Cell. [36]. 
Therefore, the size of charge controller needed for a given system can be calculated as in [37] with the formula

Where

$$
I_{c}=1.25 \times\left(I_{s c} \times P V_{n}\right)
$$

Where

$I_{c}$ : Charge controller current rating

$I_{s c}$ : Short circuit current

$P V_{n}$ : Number of PV panels.

\section{F. PV energy system modeling}

Photovoltaic cell is a semiconductor device, which can convert solar energy to electrical energy. Connecting a number of the cells in series or in parallel improves their output characteristics [36]. Figure 13 shows the equivalent circuit of a typical photovoltaic cell. From the diagram, the photovoltaic cell is modeled as expressed below.

Neglecting the resistors for simplification of the circuit diagram, the output current of the PV array will be;

$$
I_{P v}=N_{P} I_{P h}-N_{P} I_{s a t}\left[\exp \left(\frac{q}{n k} \frac{V_{P v}}{N_{S}}\right)-1\right]
$$

Where

$I_{P v}:$ PV array current

$I_{P h}:$ Photodiode current

$N_{P}$ : Number of cells in parallel

$I_{\text {sat }}$ : reverse saturation of the $\mathrm{PV}$ cell

$q$ : Electron charge $=1.6 \times 10^{-19}$ Coulomb

$V_{P v}:$ PV array voltage

$N_{s}$ : Number of array in series

$n$ : Ideal factor of P-N junction (chosen from 1 to 5 )

$k$ : Boltzmann constant $=1.3 \times 10^{-23} \mathrm{~J} /{ }^{\circ} \mathrm{K}$

Also, reverse saturation is given as;

$$
I_{P h}=I_{S C T_{0}} x S_{i}+K_{i}\left(T-T_{0}\right)
$$

Where;

$T_{0}$ : Reference temperature of the cell

$T$ : Temperature of the PV array in ${ }^{\circ} \mathrm{K}$

$K_{i}$ : Temperature coefficient

$S_{i}$ : Irradiance

$I_{S C T_{0}}: P V$ short circuit current at $T 0$

$I_{0}:$ reverse saturation of the cell at $T_{0}$

$E_{\text {gap }}:$ Air gap voltage

$$
I_{\text {sat }}=I_{0} \times\left(\frac{T}{T_{0}}\right)^{\frac{3}{n}} \times\left[\frac{q E_{\text {gap }}}{n k}\left(\frac{1}{T_{0}} \frac{1}{T}\right)\right]
$$

Since power is the product of current and voltage, the output power of a PV will give

$$
P_{P v}=I_{P v} V_{P v}
$$

Substituting (8) into (11), the output power becomes

$$
P_{P v}=N_{P} I_{P h} V_{P v}-N_{P} I_{s a t} V_{P v}\left[\exp \left(\frac{q}{n k} \frac{V_{P v}}{N_{S}}\right)-1\right]
$$

\section{G. Operating Strategy}

This work will concentrate more on meeting the energy demand of the academic environment using photovoltaic system. The installation will be at two locations in the school. The system will operate in such a way that the photovoltaic system will be able to fully provide the energy needed from the battery to satisfy the daily energy demand of the academic area. The battery will also be charged from the utility when the utility is available and if it becomes necessary. It will also be a bit oversized so that in the event of excess generation from the Photovoltaic system, this excess energy will be stored in the battery and then serve as a reserve for the system. The reserve will then be used when generation is low or during system maintenance.

\section{Results and Discussion}

Table 2. Inverter technical data.

\begin{tabular}{ll}
\hline Inverter Type & PVS800-57-0250kW-A \\
Nominal AC output power & $250 \mathrm{~kW}$ \\
Nominal AC current & $485 \mathrm{~A}$ \\
Nominal output voltage & $300 \mathrm{~V}$ \\
Output frequency & $50 / 60 \mathrm{~Hz}$ \\
Harmonic distortion, current & $<3 \%$ \\
Power factor compensation & Yes \\
DC voltage range & 450 to $750 \mathrm{~V}$ \\
\hline
\end{tabular}

From table 2 above, it is shown that the selected system inverter is $250 \mathrm{~kW} 480 \mathrm{~V}$ inverter. In considering the connected load of $204 \mathrm{~kW}$, it can be observed that the actual inverter size should be $255 \mathrm{~kW}$. This implies a higher inverter size which can result to over-sizing. But if diversity factor is considered regarding the connected load, it can be concluded that the selected inverter satisfies the requirement.

Table 3. Battery specification

\begin{tabular}{ll}
\hline Required battery capacity & $2798.5 \mathrm{kWh}$ \\
Battery in series & 20 \\
Batteries in parallel & 3731 \\
Battery rating & $24 \mathrm{~V} 750 \mathrm{AH}$ \\
\hline
\end{tabular}

Table 3 shows the calculated battery capacity. It was obtained by considering a 1.5 day of autonomy. The essence of this is to ensure that there is reserve in the battery in the event of low generation. It will also make it easy for the system to handle excess generation.

Table 4. PV technical data.

\begin{tabular}{ll}
\hline Selected PV & $250 \mathrm{~W} 24 \mathrm{~V}$ \\
Daily required energy & $1359 \mathrm{kWh}$ \\
PV daily output & $1445 \mathrm{kWh}$ \\
Number of PV in series & 20 \\
Number of PV in parallel & 1000 \\
\hline
\end{tabular}

From table 4 , the selected panel is $250 \mathrm{~kW} 24 \mathrm{~V}$. The photovoltaic system will only satisfy daily demand. This is expected to generate $1445 \mathrm{kWh}$ daily at an efficiency of 0.85 . Although there may be times when generation will be less than required, this will not be much of a problem because the system is grid connected and there is high likelihood of getting supply from the utility at least for few hours in a day. 


\section{Conclusion}

With increased research in photovoltaic system today, it will in the near future become so popular and a major source of electricity generation. In this project, a photovoltaic system was sized to meet the daily energy demand of a polytechnic in Nigeria. The system is to be installed at two different locations with same system specifications. It is expected that the system may not be able to meet the demands in some Months with lower solar radiation. This should not be of much problem since it is a grid connected system as the batteries will equally be charged from the grid. It is recommended that further work on this will be to incorporate wind generation to the system as it has been established that the location has reasonable wind speed.

\section{References}

[1] K. Vikas, N. Savita, and B. Prashant, "Status of solar wind renewable energy in India," Renew. Sustain. Energy Rev., vol. 27, pp. 1-10, Nov. 2013.

[2] T. Adefarati and R. C. Bansal, "The Impacts of PV-Wind-Diesel-Electric Storage Hybrid System on the Reliability of a Power System," Energy Procedia, vol. 105, pp. 616-621, May 2017.

[3] "Electricity Production Data | World Electricity Statistics | Enerdata." [Online]. Available: https://yearbook.enerdata.net/electricity/world-electricity-prod uction-statistics.html. [Accessed: 14-Aug-2018].

[4] N. H. Samrat, N. B. Ahmad, I. A. Choudhury, and Z. B. Taha, "Modeling, Control, and Simulation of Battery Storage Photovoltaic-Wave Energy Hybrid Renewable Power Generation Systems for Island Electrification in Malaysia," Sci. World J., vol. 2014, 2014.

[5] O. Hafez and K. Bhattacharya, "Optimal planning and design of a renewable energy based supply system for microgrids," Renew. Energy, vol. 45, pp. 7-15, Sep. 2012.

[6] B. Mangu, S. Akshatha, D. Suryanarayana, and B. G. Fernandes, "Grid-Connected PV-Wind-Battery-Based Multi-Input Transformer-Coupled Bidirectional DC-DC Converter for Household Applications,” IEEE J. Emerg. Sel. Top. Power Electron., vol. 4, no. 3, pp. 1086-1095, Sep. 2016.

[7] "Renewable energy | Statistical Review of World Energy Energy economics | BP," bp.com. [Online]. Available: https://www.bp.com/en/global/corporate/energy-economics/st atistical-review-of-world-energy/renewable-energy.html. [Accessed: 23-Aug-2018]

[8] "Statistics | Africa - Share of sources in renewable electricity generation (chart)." [Online]. Available: https://www.iea.org/statistics/?country=AFRICA\&year=2015 \&category $=\mathrm{Key} \% 20$ indicators\&indicator $=$ ShareRenewGen\& mode $=$ chart\&categoryBrowse $=$ false .

[Accessed: 23-Aug-2018].

[9] E. O. Eleri, O. Ugwu, and P. Onuvae, "EXPANDING ACCESS TO PRO-POOR ENERGY SERVICES IN NIGERIA," p. 18.
[10] S. Dutta, "DFID/ENERGIA project on Gender as a Key Variable in Energy Interventions, December 2005," p. 76.

[11] O. Editor, "65\% of Nigerian Schools Lack Electricity," THISDAYLIVE, 19-Jul-2017.

[12] "Electricity and education: The benefits, barriers, and recommendations for achieving the electrification of primary and secondary schools.:. Sustainable Development Knowledge Platform." [Online]. Available: https://sustainabledevelopment.un.org/index.php?page=view\& type $=400 \& n r=1608 \&$ menu $=35$. [Accessed: 23 -Aug-2018] .

[13] M. Kanagawa and T. Nakata, "Assessment of access to electricity and the socio-economic impacts in rural areas of developing countries," Energy Policy, vol. 36, no. 6, pp. 20162029, Jun. 2008.

[14] “Nigeria," Wikipedia. 25-Aug-2018.

[15] C. Ekeh, "Issues and challenges of power sector reforms in a depressed economy," in 2008 5th International Conference on the European Electricity Market, 2008, pp. 1-7.

[16] N. Edomah, C. Foulds, and A. Jones, "Energy Transitions in Nigeria: The Evolution of Energy Infrastructure Provision (1800\&\#8211; 2015),” 2016. [Online]. Available: https://www.ingentaconnect.com/content/doaj/19961073/2016 /00000009/00000007/art00007. [Accessed: 27-Aug-2018].

[17] O. I. Okoro and E. Chikuni, "Power sector reforms in Nigeria: opportunities and challenges," J. Energy South. Afr., vol. 18, no. 3, p. 6, 2007.

[18] A. S. Sambo, "Matching Electricity Supply with Demand in Nigeria," Int. Assoc. Energy Econ., p. 5, 2008.

[19] N. Edomah, "Modelling Future Electricity: Rethinking the Organizational Model of Nigeria's Electricity Sector," IEEE Access, vol. 5, pp. 27074-27080, 2017.

[20] "Hussaini Adamu Federal Polytechnic," Wikipedia. 30-Aug-2017.

[21] "Home." [Online]. Available: http://www.hafedpoly.edu.ng/. [Accessed: 28-Aug-2018].

[22] J. Kazaure and I. Basiru, "Electrical Power Demand and Supply: A Case Study of Hussaini Adamu Federal Polytechnic".

[23] Y. N. Udoakah and M. D. Umoh, "Sustainably meeting the energy needs of Nigeria: The renewable options," in 2014 IEEE International Energy Conference (ENERGYCON), 2014, pp. 326-332.

[24] A. S. Sambo, "Strategic Developments In Renewable Energy In Nigeria," p. 5, 2009.

[25] Nigeria's Wind Energy Potentials: the Path to a Diversified Electricity Generation-Mix.

[26] I. Wole-Osho, O. Bamisile, H. Adun, and I. Yusuf, "Comparison of renewable energy potential in relation to renewable energy policy in ECOWAS countries," in 2016 HONET-ICT, 2016, pp. 24-28.

[27] F. Igbinovia, "AN OVERVIEW OF RENEWABLE ENERGY POTENTIALS IN NIGERIA: PROSPECTS, CHALLENGES AND THE WAY FORWARD," Energ. J. ISSN 0375-8842, vol. Index 46 507, pp. 570-579, Nov. 2014. 
[28] "Kazaure, Nigeria Travel Weather Averages (Weatherbase)," Weatherbase. [Online]. Available: http://www.weatherba.se/weather/weatherall.php3?s=603934 \&cityname=Kazaure-Jigawa-Nigeria\&units=us. [Accessed: 06-Sep-2018].

[29] "National Renewable Energy and Energy Efficiency Policy for Nigeria, 2015." 2015.

[30] P. Bajpai and V. Dash, "Hybrid renewable energy systems for power generation in stand-alone applications: A review," Renew. Sustain. Energy Rev., vol. 16, no. 5, pp. 2926-2939, Jun. 2012.

[31] K. Gunavardhan, D. I. P. Reddy, and D. P. Sujatha, "Grid Connected Hybrid (PV-Wind-Battery) System with Bidirectional DC-DC Converter," vol. 5, no. 4, p. 7, 2017.

[32] S. C. Smith, P. K. Sen, B. Kroposki, and K. Malmedal, "Renewable energy and energy storage systems in rural electrical power systems: Issues, challenges and application guidelines," in 2010 IEEE Rural Electric Power Conference (REPC), 2010, pp. B4-B4-7.
[33] S. O. Amrouche, D. Rekioua, and T. Rekioua, "Overview of energy storage in renewable energy systems," in 2015 3rd International Renewable and Sustainable Energy Conference (IRSEC), 2015, pp. 1-6.

[34] M. Farhadi and O. Mohammed, "Energy Storage Technologies for High-Power Applications," IEEE Trans. Ind. Appl., vol. 52, no. 3, pp. 1953-1961, May 2016.

[35] F. J. Ardakani, G. Riahy, and M. Abedi, "Optimal sizing of a grid-connected hybrid system for north-west of Iran-case study," in 2010 9th International Conference on Environment and Electrical Engineering, 2010, pp. 29-32.

[36] M. Memar, M. Moazzami, H. Shahinzadeh, and D. Fadaei, "Techno-economic and environmental analysis of a grid-connected photovoltaic energy system," in 2017 Conference on Electrical Power Distribution Networks Conference (EPDC), 2017, pp. 124-130.

[37] F. Grouz and L. Sbita, "A safe and easy methodology for design and sizing of a stand-alone hybrid PV-wind system," in 2014 International Conference on Electrical Sciences and Technologies in Maghreb (CISTEM), 2014, pp. 1-8. 